\title{
Successful Surgical Retrieval of a Urinary Foreign Body by Cystotomy in Labrador Retriever Dog: A Case Report
}

\author{
Mamta Mishra*, Akash, Dipanshu Bisht and S. K. Maiti \\ Division of Surgery, ICAR-Indian Veterinary Research Institute, \\ Izatnagar, Bareilly, (UP) 243122, India \\ *Corresponding author
}

A B S T R A C T

\section{Keywords \\ Urolith, Cystotomy, Struvite, Foreign Body, Urinary Tract Infection \\ Article Info \\ Accepted: \\ 15 March 2020 \\ Available Online: \\ 10 April 2020}

A 7 yrs old uncastrated male Labrador retriever dog was presented to Teaching Veterinary Clinical Complex with a history of frequent vomition, discomfort and anorexia. On Further anamnesis it was found that the dog was frequently voiding urine in small volumes which was followed by few drops of blood. The abdominal radiograph revealed multiple bladder stones with larger one surrounding a urinary catheter. The uroliths were removed through cystotomy and diagnosed as struvite, which is predominantly a resultant of foreign body and urinary tract infection.

\section{Introduction}

Struvite has the higher incidence rates among canine uroliths, and the most common cause of struvite urolithiasis in dogs is infection with urease-producing organisms (Osborne et al., 1995). Supersaturation of urine is the prerequisite for the formation of struvite calculi (Griffith, 1979). $80 \%$ of calculi removed from dogs in the United States confirmed the mineral composition equivalent to struvite (Brown et al., 1977). Sixty percent of the cases confirmed presence of struvite calculi in female dogs of 4-7 years of age
(Finco et al., 1970). Struvite calculi are located most frequently in the urinary bladder, and are usually associated with staphylococcal UTI (Weaver and Pillinger, 1975). Crystals are constantly precipitating and dissolving in the urine of normal dogs without forming visible stones (Senior DF and Finlay, 1986).

The initiation of urolith formation (nucleation) or the nidus formation is influenced by many interrelated physiologic and pathologic events, but the essential requirement is super saturation of the urine 
with calculogenic substances (Osborne et al., 1985; Senior DF and Finlay, 1986). Other conditions that promote nucleation are alkaline $\mathrm{pH}$ that reduces the solubility of crystalline material, the presence of an organic matrix that crystals can adhere to, or a substance or object that can act as a template for organizing and modifying growth of crystals. Under any of these conditions, precipitation of crystals occurs at a lesser degree of supersaturation (Lulich et al., 1995).

The hematuria, high urinary $\mathrm{pH}$, and multiple struvite crystals observed in this dog suggested an acute UTI with a ureaseproducing organism, such as staphylococci or Proteus spp. Studies have shown that struviteuroliths can form in 2 to $8 \mathrm{wk}$ when urease-producing staphylococci cause UTI (Klausner et al., 1980).

\section{Case history and observations}

A 7 yrs old, $35.9 \mathrm{~kg}$ uncastrated male was presented to the Veterinary Clinic with a history of vomition, dysuria, urinary incontinence, discomfort and anorexia past 1 week. The owner also complained of foul smelling urine. Abdominal as well as per rectal palpation was suggestive of a hard cylindrical mass within urinary bladder, urinary catheterization was attempted but was unsuccessful. The dog was oligouric and showing symptoms of stranguria.

Urinalysis revealed isosthenuric urine, with $9.0 \mathrm{pH}$. Abdominal Radiograph confirmed the presence of multiple radiopaque masses with the larger mass being $8.6 \times 2 \mathrm{~cm}$ in size entrapping a foreign body in the centre (Figure 1). It appeared to be covering whole of bladder. The condition was tentatively diagnosed as urinary foreign body associated urolith.

\section{Surgical procedure}

Initially the dog was stabilized with Normal Saline solution, prophylactic administration of ceftriaxone (50 $\mathrm{mg} / \mathrm{kg} \quad$ b.wt.) i/v, dexamethasone (1mg/kg b.wt.), meloxicam $(0.4 \mathrm{mg} / \mathrm{kg}$ b.wt. $) \mathrm{i} / \mathrm{m}$ and animal was prepared for aseptic surgery. The dog was premedicated with Atropine sulphate (0.02 $\mathrm{mg} / \mathrm{kg}$ b.wt.) i/m, Xylazine (1 mg/kg b.wt.) $\mathrm{i} / \mathrm{m}$. Anaesthesia was induced with Ketamine $(5 \mathrm{mg} / \mathrm{kg} \quad$ b.wt. $) \mathrm{i} / \mathrm{m}$ and maintained with Isofluranae. The animal was taken into Dorsalrecumbancy, a midline coeliotomy was performed extending from the umbilicus to the pubis.

A stab incision was made into the apex of the bladder and urine was aspirated. The bladder wall was thick but the bladder did not collapse completely when emptied. The stab incision was extended caudally along the ventral aspect of the bladder revealing a large immovable calculus that extended into the bladder neck (Figure 2). The foreign body was a urinary catheter covered by mineral deposit (Figure 3). One end of the urinary catheter was smooth. There were many small calculi and a three large urolith of about 0.9 , $1.0 \mathrm{~g}, 1.6 \mathrm{~g}$ (weight) had grown from three different portions of the catheter adjacent to the bladder entrance into the bladder. The remainder of the foreign body could then be manipulated into the bladder and removed.

The cystotomy was closed with a simple interrupted $3 / 0$ polydioxanone sutures. The surgical wound was closed by 3 layer suturing, firstly the muscular layer, then the subcutaneous tissue and later skin were closed in separate layer.

An indwelling no.8 urinary catheter was introduced and maintained for $72 \mathrm{~h}$ after surgery to monitor urine output and to ensure the bladder was constantly drained. Post 
operatively, ceftriaxone plus tazobectum (50 $\mathrm{mg} / \mathrm{kg}$ b.wt. $) \quad \mathrm{i} / \mathrm{v}$, meloxicam $(0.2 \mathrm{mg} / \mathrm{kg}$ b.wt.) $i / v$, advised the owner to maintain the dog on fluid therapy with $5 \%$ dextrose, $\mathrm{i} / \mathrm{v}$ for next 5 days and feeding of soft semi-solid palatable diet postoperatively atleast for 7 days.

\section{Results and Discussion}

Foreign bodies in the urinary bladder are uncommon but till date such cases has been recorded in dogs (Denny,1972; Zanotti et al., 1989), cats (Andre and Jackson,1972), other animals (Hamlen,1972), and also in humans
(Elder JS and Young LW,1986).As per the Clinical reports in the literature suggest, and experimental studies confirm, that a vesical foreign body does not invariably induce calculus formation (Denny HR,1972; Andre PG and Jackson OF,1972; Hamlen H,1972).

The reason for presence of vesicular foreign body may be either traumatic migration from other organs, or iatrogenically during surgery or during manipulation of the urinary tract. Auto introduction of such objects into the urinary bladder through urethra has also been reported in humans (Elder and Young, 1986).

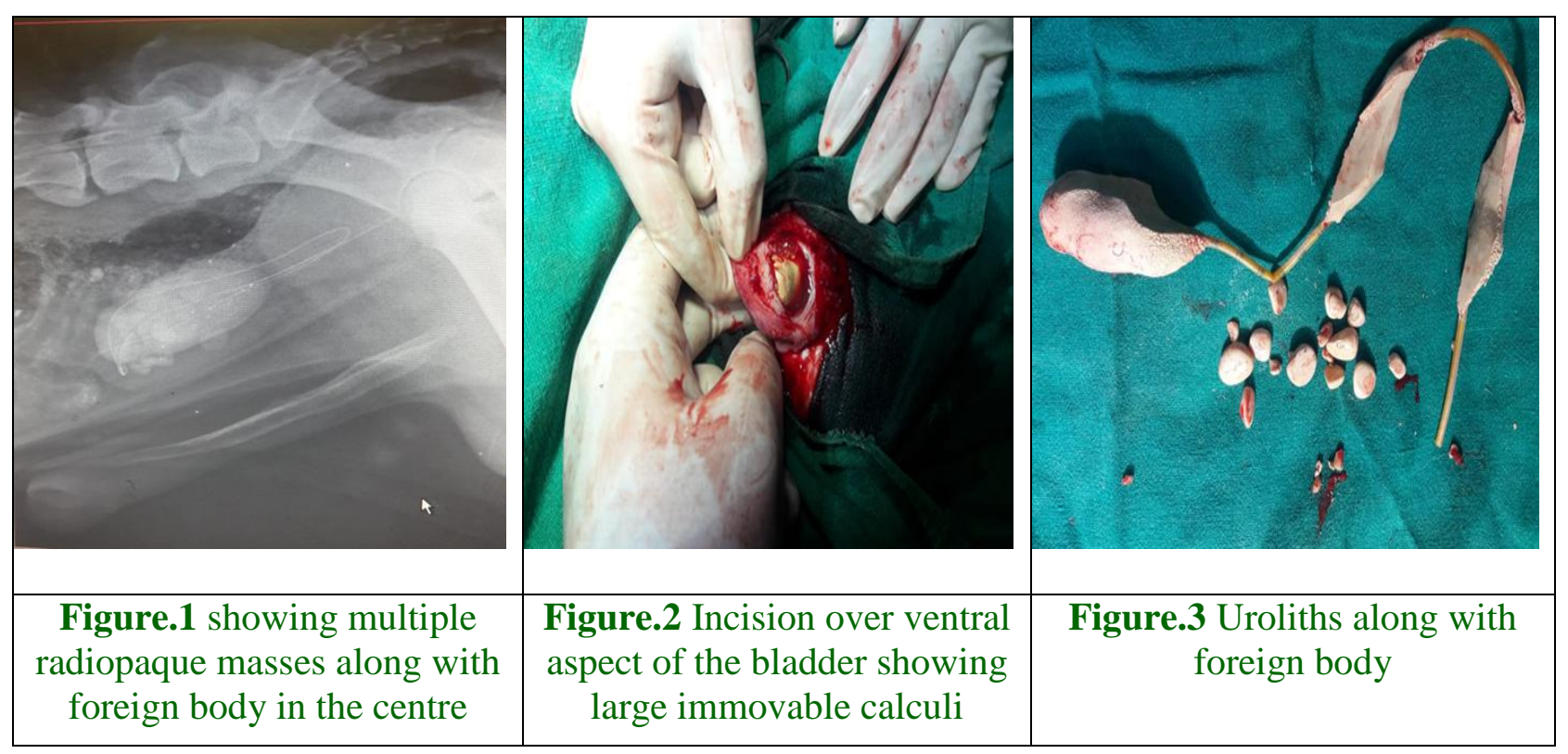

Clinical literature showed objects insertion into the urethra for sexual gratification, or by paediatric, psychiatric or intoxicated patients (Eckford et al., 1992) using items such as a razor blade (Saunders et al., 1992) and a thermometer (Patterson and Chilton, 1995) Iatrogenic foreign bodies reported include a urethral stent (Smith and Firlit, 1997). Urinary calculi in humans, secondary to urinary tract foreign bodies, have often been related to indwelling catheters, fragments of Foley balloon catheters, and non-absorbable sutures penetrating the bladder mucosa (Elder and Young, 1986). Foreign bodies, such as oxtail awns, urinary catheters, bullets, blood clots, and necrotic tissue, as well as suture material, have been found at the nidus of canine uroliths (Lulich et al., 1995).

In this case, the history and surgical findings indicate that the urinary catheter was initially inserted for maintaining patent urine outflow but because of owner's negligence it moved into bladder and was there for more than 4 months. Because of thin, linear and flexible nature of catheter is penis didn't prevented 
retrograde insertion of the catheter into the bladder through urethra. Presence of foreign body also provoked ascending Urinary tract infection into the bladder that was tested prior to surgery.

\section{References}

Andre PG and Jackson OF(1972) Lead foreign body in a cat's bladder. J Small AnimPract. 13: 101-102.

Brown NO, Parks JL and Green RW (1977) Canine urolithiasis: Retrospective analysis of 438 cases. J Am Vet Med Assoc. 170:414-418.

Denny HR (1972) An unusual cause of urethral obstruction in the dog. J Small AnimPract. 13: 339-341.

Eckford SD, Persad RA, Brewster SF and Gingell JC (1992) Intravesical foreign bodies: five year review. Br J Urol. 69:41-4.

Elder J and Young LW (1986) Calcified vesical foreign body. Am J Dis Child. 140: 55-56.

Finco DR, Rosin E and Johnson KH (1970) Canine urolithiasis: A review of 133 clinical and 23 necropsy cases. J Am Vet Med Assoc. 157:1225-1228.

Griffith DP (1979) Urease stones.Urol Res. 7:215221.

Hamlen H (1993) Pyelonephritis in a mature gelding with an unusual urinary bladder foreign body: A case report. J Equine Vet Sci. 13: 159-162.

Klausner JS, Osborne CA, O'Leary TP, et al., (1980) Experimental induction of struviteuroliths in miniature schnauzer and beagle dogs. Invest Urol. 18: 127-132.

Lulich JP, Osborne CA, Bartges JW and Polzin
DJ (1995) Canine lower urinary tract disorders. Urolithiasis: Biologic behavior. In: Ettinger SJ, Feldman EC, eds. Textbook of Veterinary Internal Medicine. 4th ed. Vol 2. Philadelphia: WB Saunders. 1840.

Lulich JP, Osborne CA, Bartges JW andPolzin DJ (1995) Canine lower urinary tract disorders. Urolithiasis: Rare and unusual uroliths. In: Ettinger SJ, Feldman EC, eds. Textbook of Veterinary Internal Medicine. 4th ed. Vol 2.Philadelphia: WB Saunders.1858-1859.

Osborne CA, Lulich JP, Bartges JW, et al., (1995) Canine and feline urolithiasis: Relationship of etiopathogenesis to treatment and prevention. Canine struviteurolithiasis. In: Osborne CA, Finco DR, eds. Canine and Feline Nephrology and Urology. Baltimore: Williams \& Wilkins.851-865.

Patterson JE and Chilton CP (1995) Intra-vesical foreign body: an unusual cause. $\mathrm{Br} \mathrm{J}$ ObstetGynaecol.102:838.

Saunders MS, Bitonte AG and McElroy JB (1992) The improbable intravesical foreign body. South Med J. 85:653-655.

Senior DF and Finlayson B (1986) Initiation and growth of uroliths. Vet Clin North Am Small AnimPract. 16: 27-44.

Smith DP and Firlit C (1997) Balloon-wire retrieval of a migrated urethral stent in the early postoperative period.Urology.50:160161.

Weaver AD and Pillinger R (1975) Relationship of bacterial infection in urine and calculi to canine urolithiasis. Vet Rec. 97:48-50.

Zanotti S, Kaplan P, Garlicj D and Lamb C (1989) Endocarditis associated with a urinary bladder foreign body in a dog. J Am AnimHosp Assoc. 25: 557-561.

\section{How to cite this article:}

Mamta Mishra, Akash, Dipanshu Bisht and Maiti, S. K. 2020. Successful Surgical Retrieval of a Urinary Foreign Body by Cystotomy in Labrador Retriever Dog: A Case Report. Int.J.Curr.Microbiol.App.Sci. 9(04): 1300-1303. doi: https://doi.org/10.20546/ijcmas.2020.904.153 